\title{
PENGARUH PEMBERIAN EKSTRAK ETANOL DAUN PARANG ROMANG (Boehmeria virgata) SECARA SUBKRONIS ORAL TERHADAP PROFIL HEMATOLOGI TIKUS PUTIH (Rattus Novergicus)
}

\author{
Magfirah, Mufidah dan Marianti A. Manggau \\ Fakultas Farmasi, Universitas Hasanuddin, Makassar
}

Kata Kunci :

Toksisitas subkronis, Ekstrak etanol daun parang romang, profil hematologi

\begin{abstract}
ABSTRAK
Penelitian ini bertujuan untuk mengetahui pengaruh pemberian secara subkronis oral ekstrak etanol daun parang romang selama 28 hari pada profil hematologi tikus putih meliputi kadar eritrosit, leukosit, trombosit dan hemaglobin. Tikus dikelompokkan secara acak menjadi 4 kelompok, masing-masing kelompok yaitu kelompok 1 diberikan aquadest, kelompok 2 ekstrak etanol daun parang romang 250 $\mathrm{mg} / \mathrm{kgBB}$, kelompok 3 ekstrak etanol daun parang $500 \mathrm{mg} / \mathrm{kg}$ BB dan kelompok 4 ekstrak etanol parang romang $1000 \mathrm{mg} / \mathrm{kgBB}$. Hasil penelitian diperoleh nilai rata-rata tikus jantan dan betina masing-masing yaitu profil kadar eritrosit 8,56 $\pm 0,33,8,17 \pm 0,29,7,13 \pm 0,15,6,90 \pm 0,99$ dan 6,70 $\pm 0,47,6,80 \pm 0,47$, $7,60 \pm 0,24,7,40 \pm 0,24$. Trombosit 1112,00 $\pm 53,07,1099,00 \pm 58,62,1129,60 \pm 63,18$ dan 1229,00 \pm 71,27 dan $805,33 \pm 2,16,873,33 \pm 2,81,1112,30 \pm 58,32,1196,00 \pm 1,08$, Hemoglobin $15,06 \pm 0,57,14,01$ $\pm 0,28,12,83 \pm 0,14,12,26 \pm 1,81$ dan $12,56 \pm 1,18,13,23 \pm 0,76,13,9 \pm 0,32,13,53 \pm 0,28$. Profil kadar eritrosit, trombosit, hemaglobin pada tikus jantan dan betina masih dalam kisaran normal pada kelompok perlakuan dan kelompok kontrol. Untuk profil kadar leukosit 22,88 $\pm 3,52,22,90 \pm 1,26,23,90$ $\pm 0,49,24,56 \pm 4,14$ dan $22,76 \pm 7,97,14,46 \pm 2,30,16,79 \pm 1,90,14,58 \pm 1,79$. Nilai rata-rata leukosit kelompok kontrol dan kelompok perlakuan tikus jantan serta kelompok perlakuan tikus betina tidak berada pada kisaran normal sedangkan untuk kelompok perlakuan tikus betina berada pada kisaran nilai normal. Hasil uji statistik one way anova pemberian ekstrak etanol daun parang romang setelah 28 hari pada profil hematologi tikus jantan dan betina diperoleh Nilai $p>0,05$ menunjukkan bahwa pemberian ekstrak etanol daun parang romang secara oral selama 28 hari tidak mempengaruhi profil hematologi tikus putih. Dapat disimpulkan bahwa pemberian ekstrak etanol daun parang romang selama 28 hari tidak memiliki efek toksis terhadap profil hematologi tikus putih ( Rattus novergicus).
\end{abstract}

\section{PENDAHULUAN}

\section{Masuk 20-07-2018 \\ Revisi 26-07-2018 \\ Diterima 30-07-2018}

Korespondensi

\section{Marianti A Manggau} winati04@yahoo.co.id

Fakultas Farmasi, Universitas Hasanuddin Jalan Perintis Kemerdekaan Km.10, Makassar 90245 , Indonesia

Telp. +62-411-588-556 Fax. $+62-411-585-188$

Copyright

C 2018 Majalah Farmasi Farmakologi Fakultas Farmasi · Makassar

Diterbitkan tanggal 31-07-2018

Dapat Diakses Daring Pada:

http://journal.unhas.ac.id /index.php/mff
Penggunaan tanaman obat di Indonesia merupakan bagian dari budaya bangsa dan telah dimanfaatkan oleh masyarakat sejak berabad-abad yang lalu. Namun demikian, secara umum efektivitas dan keamanannya belum sepenuhnya didukung hasil penelitian yang memadai mengingat hal tersebut dan menyadari bahwa Indonesia sebagai mega-center tanaman obat di dunia, maka perlu adanya penelitian berkesinam-bungan sehingga tumbuhan yang secara empiris telah digunakan oleh masyarakat Indonesia dapat dipertanggungjawabkan secara ilmiah. Parang romang atau Boehmeria virgata (Forst) Guil (B. virgata) yang termasuk dalam suku Urticaceae adalah salah satu obat yang digunakan secara empiris oleh pengobat suku Makassar Sulawesi Selatan sebagai obat anti tumor (1)

Ekstrak etanol parang romang beserta 3 tanaman obat masyarakat Makassar yang lain yaitu Acanthus ilicifolius Linn, Acalyphaindica L. dan Eupatorium odoratum telah diteliti aktivitasnya terhadap sel HeLa dan dilaporkan bahwa $B$. virgata memiliki aktivitas tertinggi dengan nilai IC50 berturut-turut yaitu 9,40; 32,81; 179,02 dan $223,64 \mu \mathrm{g} / \mathrm{ml}$ (2). Sitotoksisitas selektif ekstrak etanol daun B. virgata terhadap beberapa cell lines kanker yaitu HeLa, Widr, T47D dan Vero cell lines serta berturut-turut nilai IC50 yang dihasilkan yaitu $8,991 \pm 0.234 ; 18,925 \pm 1,277 ; 12,732 \pm 0,945$ dan $16,022 \pm 0,663 \mu \mathrm{g} / \mathrm{ml}$ dengan masing-masing selektif indeks (SI) yaitu sebesar 0,844; 0,847; 1,258 dan 1,000 (3).

Penelitian in vitro telah dilakukan masih perlu dilanjutkan ke uji preklinik secara in vivo untuk menentukan dosis dan keamanan ekstrak etanol $B$. virgata. Hal ini merupakan usaha untuk mengantisipasi pasar global obat tradisional untuk dapat diterima masyarakat global maupun dapat diikutsertakan dalam pelayanan kesehatan untuk tujuan promotif, preventif dan rehabilitatif. Untuk itu perlu dilakukan uji toksisitas subkronis oral pada tikus sehat untuk mengetahui pengaruh ekstrak terhadap profil hematologi (4). Melalui penelitian ini diharapkan diperolehnya informasi pengaruh pemberian ekstrak etanol daun parang romang terhadap profil hematologi. Dengan demikian, ekstrak etanol daun parang romang diharapkan dapat menjembatani pengembangan obat tradisional ke arah pemanfaatan dalam pelayanan kesehatan formal. 


\section{METODE PENELITIAN}

\section{Alat dan Bahan Penelitian}

Peralatan yang digunakan adalah kandang hewan, alat-alat gelas yang biasa digunakan, vaculab EDTA, Kanula, Spoit 1 dan $3 \mathrm{cc}$, timbangan analitik (Sartorius), Hematologi Analyzer (Sysmex XS-8000i)

Bahan yang digunakan yaitu Daun parang romang (B. virgata Linn (Forst) Guill), air suling, alkohol, tikus putih, dan pakan tikus.

\section{Penentuan sumber data}

Subjek dari penelitian ini adalah tikus putih jantan dan betina yang memiliki kriteria inklusi untuk jantan: Tikus putih dengan berat badan 180-200 gram, sehat, umur 2 bulan. Kriteria inklusi untuk betina: Berat badan 150-170 gram, sehat, tidak hamil dan umur 2 bulan. Jumlah tikus yang digunakan pada penelitian adalah sebanyak 40 ekor dengan jumlah masing- masing 20 ekor jantan dan 20 ekor betina.

\section{Pemilihan dan Penanganan Hewan Uji}

Tikus dipelihara dengan kondisi tertentu $(12: 12 \mathrm{~h}$ siklus cahaya:gelap). Untuk setiap perlakuan, tikus yang digunakan adalah 10 ekor setiap grup yang terdiri dari 5 betina dan 5 jantan. Hewan uji diperlakukan sesuai dengan standard the Institutional Animal Ethics Committee (IAEC). Prosedur pengujian padapenelitian ini dilaporkan ke Komisi Etik Universitas Hasanuddin untuk mendapatkan persetujuan.

\section{Ekstraks}

Sebanyak 1,4 kg serbuk daun tumbuhan parang romang $(B$. virgata) dimaserasi dengan etanol sebanyak 15 L selama 5 hari, kemudian campuran sampel dan pelarut ini disaring hingga diperoleh ekstrak dan ampas. Ampas yang dihasilkan kemudian dimaserasi kembali dengan pelarut yang sama. Seluruh ekstrak yang diperoleh disatukan dan dipekatkan dengan Rotary Vacum Evaporator sampai diperoleh ekstrak etanol pekat.

\section{Pembuatan Larutan Uji Ekstrak etanol daun parang romang}

Pembuatan larutan ekstrak etanol daun parang romang dibuat segar setiap hari dengan 3 variasi dosis yaitu :

Dosis $250 \mathrm{mg} / \mathrm{KgBB}$ : Ekstrak etanol daun parang romang ditimbang sebanyak $500 \mathrm{mg}$ dengan timbangan analitik kemudian dilarutkan dengan aquadest sebanyak $20 \mathrm{ml}$.

Dosis $500 \mathrm{mg} / \mathrm{KgBB}$ : Ekstrak etanol daun parang romang ditimbang sebanyak $1000 \mathrm{mg}$ dengan timbangan analitik kemudian dilarutkan dengan aquadest sebanyak $20 \mathrm{ml}$.

Dosis $1000 \mathrm{mg} / \mathrm{KgBB}$ : Ekstrak etanol daun parang romang ditimbang sebanyak $2000 \mathrm{mg}$ dengan timbangan analitik kemudian dilarutkan dengan aquadest sebanyak $20 \mathrm{ml}$.

\section{Uji Toksisitas subkronis (4).}

Uji toksisitas subkronis pada penelitian ini menggunakan prosedur BPOM 2014, menggunakan 10 ekor tikus (5 tikus jantan dan 5 tikus betina) perkelompok dengan 3 variasi dosis yaitu dosis terendah $250 \mathrm{mg} / \mathrm{KgBB}$, dosis tengah 500 $\mathrm{mg} / \mathrm{KgBB}$ dan dosis tinggi yaitu $1000 \mathrm{mg} / \mathrm{KgBB}$. Pemberian ekstrak etanol daun parang romang diberikan setiap hari selama 28 hari. Pengamatan dilakukan terhadap hewan uji meliputi Penimbangan bobot badan tikus dan Pengamatan terjadinya gejala-gejala toksik dan gejala klinis yang berupa perubahan kulit dan bulu, lethargi, tremor, konvulsi, diare, kematian dan tingkah laku yang aneh (misalnya berjalan mundur) dilakukan setiap hari selama 28 hari.

\section{Pemeriksaan Profil Hematologi}

Pengambilan sampel darah dilakukan sesudah pemberian ekstrak etanol daun parang romang (B. virgata) pada tikus dengan berbagai konsentrasi selama 28 hari. Pada hari ke- 29 dilakukan pengambilan darah sebanyak $1 \mathrm{ml}$. Sampel darah dikoleksi melalui vena tail kemudian dimasukkan ke dalam vaculab berwarna ungu (Vaculab EDTA), vaculab kemudian disimpan pada temperatur $2-8{ }^{\circ} \mathrm{C}$ untuk analisis profil hematologi darah rutin lebih lanjut dengan menggunakan Hematologi Analyzer (Sysmex XS-8000i), dengan prosedur sebagai berikut: Vaculab EDTA yang berisi darah tikus dikeluarkan dari CoolBOX dibiarkan selama 15 menit pada suhu $18-30{ }^{\circ} \mathrm{C}$. selama menunggu penyesuaian suhu, sampel tidak boleh dikocok dan tidak boleh terpapar cahaya matahari langsung.Status alat dicek dalam keadaan ready (lampu ready menyala hijau), muncul window (masukkan informasi sampel berupa nama, jenis kelamin, umur dan nama laboran) klik Ok setelah diset. Sampel dihomogenkan dengan cara membolak-balik vaculab dengan gerakan membentuk angka 8, sampai dibagian dasar tidak ada lagi endapan, biasanya sebanyak 20 kali atau dengan menggunakan mesin otomatis rooling. Tutup sampel (vacutube) dibuka, lalu dimasukkan ke dalam aspiration port kemudian tekan tombol start, maka lampu hijau akan berkedip dan tunggu sampai terdengar bunyi beep $2 x$ lalu sampel ditarik. kemudian hasil analisa sampel diprint.

\section{Analisis Statistik}

Data dilaporkan sebagai mean \pm standard error mean (SEM). Semua data dianalisis dengan uji normalitas Shapiro-wilk dan uji homogenitas Levene test, apabila distribusi data normal dan homogen maka, analisis data dilakukan dengan analisis varians satu arah (one-way anova) dan uji kruskall wallis untuk data yang tidak berdistribusi normal dan homogen dengan menggunakan software SPSS versi 16.0

\section{HASIL DAN PEMBAHASAN}

Pada penelitian ini daun parang romang diekstraksi dengan menggunakan metode maserasi. Filtrat hasil maserasi diuapkan dengan rotary evaporator pada suhu $60^{\circ} \mathrm{C}$ dengan kecepatan $90 \mathrm{rpm}$ kemudian dilakukan penguapan dengan sehingga diperoleh ekstrak kental. Dari metode maserasi diperoleh rendemen sebesar 8,21\% (115 gram dari 1400 gram serbuk daun parang romang) berbeda dengan hasil yang diperoleh Made shandi, rendemen ekstrak etanol daun parng romang 5,81\% (14.52 gram dari 250 gram serbuk daun parang romang).

Selanjutnya dilakukan uji toksisitas subkronis oral pada 3 tingkatan dosis sesuai dengan panduan BPOM 2014 yaitu dengan dosis tertinggi tidak lebih dari $1000 \mathrm{mg} / \mathrm{kgBB}$ dengan tingkat dosis yang rendah $250 \mathrm{mg} / \mathrm{kgBB}$, dosis menengah 500 $\mathrm{mg} / \mathrm{kgBB}$ dan dosis tertinggi $1000 \mathrm{mg} / \mathrm{KgBB}$ dengan jumlah hewan uji yang digunakan setiap kelompok sebanyak 10 ekor yang terdiri dari 5 ekor tikus jantan dan 5 ekor tikus betina, (4) untuk mengetahui pengaruh pemberian ekstrak etanol daun parang romang terhadap profil hematologi tikus putih (Rattus novergicus). Pengukuran profil hematologi pada penelitian dilakukan setelah 28 hari pemberian ekstrak etanol daun parang romang pada tikus. Nilai hematologi (profil darah) berguna untuk menilai kondisi kesehatan dan sebagai acuan nilai awal atau kontrol dalam suatu penelitian. Adanya gangguan metabolisme, penyakit, kerusakan struktur dan/atau fungsi organ, pengaruh agen/obat, dan stres dapat diketahui dari perubahan profil darah (5).

Eritrosit merupakan komponen darah yang mengandung hemoglobin yang berfungsi mengangkut oksigen dari paruparu keseluruh tubuh. Berdasarkan pada tabel 1 pengukuran 
Tabel 1. Hasil pengukuran profil hematologi tikus putih setelah pemberian ekstrak etanol daun parang romang selama 28 hari

\begin{tabular}{|c|c|c|c|c|c|}
\hline \multirow{2}{*}{ Hematologi } & \multirow{2}{*}{$\begin{array}{c}\text { Jenis } \\
\text { Kelamin }\end{array}$} & \multicolumn{4}{|c|}{ Kelompok Perlakuan } \\
\hline & & Kontrol & Dosis 1 & Dosis 2 & Dosis 3 \\
\hline \multirow{2}{*}{ Eritrosit $\left(\times 10^{6} / \mu \mathrm{l}\right)$} & Jantan & $8,56 \pm 0,33$ & $8,17 \pm 0,29$ & $7,13 \pm 0.15$ & $6.90 \pm 0,99$ \\
\hline & Betina & $6,70 \pm 0,69$ & $6,80 \pm 0,47$ & $7,60 \pm 0.24$ & $7,40 \pm 0,24$ \\
\hline \multirow{2}{*}{ Leukosit $\left(\times 10^{3} / \mu \mathrm{l}\right)$} & Jantan & $22,88 \pm 3,52$ & $22,90 \pm 1,26$ & $23,90 \pm 0.49$ & $24,56 \pm 4,14$ \\
\hline & Betina & $22,76 \pm 7,97$ & $14,46 \pm 2,30$ & $16,79 \pm 1.90$ & $14,58 \pm 1,79$ \\
\hline \multirow{2}{*}{ Trombosit $\left(\mathrm{X} 10^{3} / \mu \mathrm{L}\right)$} & Jantan & $1122,60 \pm 5,07$ & $1099,00 \pm 58,62$ & $1129,60 \pm 63.10$ & $1229,00 \pm 71,27$ \\
\hline & Betina & $805,33 \pm 2,16$ & $873,33 \pm 2,81$ & $1112,30 \pm 58.30$ & $1196,00 \pm 1,08$ \\
\hline \multirow{2}{*}{ Hemaglobin (g/dl) } & Jantan & $15,06 \pm 0,57$ & $14,01 \pm 0,28$ & $12,83 \pm 0.14$ & $12,26 \pm 1,81$ \\
\hline & Betina & $12,56 \pm 1,18$ & $13,23 \pm 0,76$ & $13,90 \pm 0.32$ & $13,53 \pm 0,28$ \\
\hline
\end{tabular}

kadar eritrosit pada kelompok kontrol, dosis 1, dosis 2 dan dosis 3 pada tikus jantan diperoleh nilai rata-rata hasil penelitian pada tikus jantan maupun tikus betina tidak ditemukan keteraturan peningkatan dosis dengan peningkatan ataupun penurunan kadar eritrosit, namun hasil pemeriksaan nilai kadar eritrosit masih dalam kisaran normal. Nilai normal eritrosit pada tikus jantan dan betina 6,2-9,6 x 106/ $\mu \mathrm{l}$ (6). Hasil uji statistik one-way anova untuk eritrosit tikus jantan dan betina diperoleh nilai $\mathrm{p}=0,179$ dan $\mathrm{p}=0,478$. Nilai p $>0,05$ menunjukkan tidak ada perbedaan bermakna kadar eritrosit kelompok perlakuan ekstrak etanol daun parang romang dengan kelompok kontrol.

Leukosit adalah komponen darah yang berfungsi untuk mengenali dan melawan mikroorganisme pada reaksi imun dan untuk membantu proses peradangan dan penyembuhan. Leukosit terdiri dari 5 komponen yaitu neutrofil, limfosit, monosit, eosinofil dan basofil. Berdasarkan pada Tabel 1 pengukuran kadar leukosit pada kelompok kontrol, dosis 1 , dosis 2 dan dosis 3 pada tikus jantan dan betina diperoleh nilai rata-rata hasil penelitian pemberian ekstrak etanol daun parang romang secara oral selama 28 hari pada profil leukosit menunjukkan peningkatan dan penurunan yang tidak jauh berbeda antara kelompok perlakuan dan kelompokkontrol. Kadar leukosit yang diperoleh pada penelitian ini baik pada kelompok kontrol maupun kelompok perlakuan berada jauh diatas nilai normal leukosit untuk tikus normal baik pada tikus jantan maupun tikus betina. Nilai normal leukosit pada tikus jantan dan betina adalah $6-17 \times 10^{3} / \mu \mathrm{l}(7)$. Hasil uji statistik one way anova leukosit untuk tikus jantan dan betina masing-masing diperoleh nilai $p=0,967$ dan $p=0,528$ $(p>0,05)$ yang menunjukkan tidak ada perbedaan bermakna kadar leukosit dan kelompok perlakuan ekstrak etanol daun parang romang selama 28 hari dengan kelompok kontrol.

Trombosit merupakan komponen darah yang berperan dalam pembekuan darah. Berdasarkan pada tabel 1 pengukuran kadar trombosit pada kelompok kontrol, dosis 1 , dosis 2 dan dosis 3 pada tikus jantan dan betina diperoleh nilai rata-rata hasil penelitian pemberian ekstrak etanol daun parang romang secara oral selama 28 hari pada kadar trombosit menunjukkan peningkatan dan penurunan yang tidak jauh berbeda antara kelompok perlakuan dan kelompok kontrol . Kadar profil trombosit masih dalam kisaran normal pada semua kelompok perlakuan dan kelompok kontrol yaitu Nilai normal trombosit pada tikus jantan $923-1580 \times 10^{3} / \mu \mathrm{l}$ dan tikus betina $797-1112 \times 10^{3} / \mu \mathrm{l}$ (8).

Hasil uji statistik one way anova pada nilai trombosit pada tikus jantan dan tikus betina diperoleh nilai $p=0,970$ dan $\mathrm{p}=0,444 \mathrm{p}>0,05$ yang menunjukkan tidak ada perbedaan bermakna kadar trombosit kelompok perlakuan ekstrak etanol daun parang romang selama 28 hari dengan kelompok kontrol.

Hemaglobin dalah senyawa pembawa oksigen yang terkandung dalam sel darah merah. Oleh karena itu, konsen- trasi $\mathrm{Hb}$ total tergantung pada jumlah sel darah merah (eritrosit) dalam sampel darah. Berdasarkan pada tabel 1 pengukuran kadar hemaglobin, pada kelompok kontrol, dosis 1 , dosis 2 dan dosis 3 pada tikus jantan dan tikus betina diperoleh nilai rata-rata hasil penelitian pemberian ekstrak etanol daun parang romang secara oral selama 28 hari pada hemoglobin menunjukkan peningkatan dan penurunan yang tidak jauh berbeda antara kelompok perlakuan dan kelompok kontrol ,namun masih dalam kisran normal. Nilai normal hemoglobin untuk tikus jantan dan betina adalah 11,6-16,1 (9). Hasil uji statistik one-way anova hemoglobin untuk tikus jantan dan tikus betina diperoleh nilai $p=0,251$ dan $p=0,639(p>0,05)$ menunjukkan tidak ada perbedaan bermakna kadar hemoglobin antara kelompok perlakuan ekstrak etanol daun parang romang selama 28 hari dengan kelompok kontrol.

Pada penelitian ini dosis yang lebih tinggi (1000 mg/kgBB) tidak ditemukan adanya keteraturan antara peningkatan dosis akan menghasilkan peningkatan efek toksik. Hal ini disebabkan efek dari beberapa tikus yang menyimpang diantara tikus yang ada dalam satu kelompok. Hasil ini menyerupai dengan penelitian yang dilakukan oleh Bo Li B, (10) yang mempelajari efek toksik jangka panjang pemberian ekstrak bunga teh. Bo Li B menemukan bahwa beberapa parameter hematologi darah tidak memiliki pola yang konsisten antara peningkatan dosis dengan perubahan parameter hematologi dan terhadap waktu pengukuran. Pola yang tidak tetap ini diduga disebabkan adanya variasi dari tikus dalam satu kelompok dan tidak dapat disimpulkan bahwa sampel uji memberikan efek toksik terhadap parameter yang diukur. Kisaran nilai hematologi normal bervariasi pada individu jantan dan betina, serta perbedaan umur. Pada umumnya eritrosit, hemoglobin, hematokrit, leukosit, dan trombosit lebih tinggi pada hewan jantan dibandingkan betina. Jumlah eritrosit meningkat seiring pertambahan umur, demikian juga kadar hemoglobin. Sebaliknya jumlah leukosit total, neutrofil, limfosit, dan trombosit menurun seiring pertambahan umur (11). Profil hematologi bervariasi tergantung dari kondisi geografis dan faktor lingkungan setempat (5).

Selain profil hematologi pada penelitian ini juga dilakukan pengamatan bobot badan tikus setiap hari. Hasil penimbangan bobot badan hewan jantan dan betina selama penelitian meningkat, terlihat bahwa berat badan rata-rata setiap minggu mengalami peningkatan. Pada studi toksisitas, hewan coba yang mendapat dosis tinggi umumnya kehilangan berat badan yang disebabkan penurunan nafsu makan. Perubahan berat badan secara nyata merupakan indikator yang paling mudah terlihat dan menjadi indikator awal adanya efek toksik dari sampel uji yang diberikan (12).

Pengamatan gejala toksisitas dilakukan setiap hari pada semua kelompok perlakuan baik pada kelompok tikus dan jantan setelah pemberian ekstrak etanol daun parang romang secara oral selama 28 hari, pengamatan yang dilakukan secara individu meliputi perubahan pada kulit dan bulu, 
lethargi, tremor, kejang, diare, berjalan mundur dan ada tidaknya kematian pada tikus. Tujuan dari pengamatan ini untuk melihat ada tidaknya efek toksis tertunda dari ekstrak etanol daun parang romang yang diberikan secara akut. Hasil pengamatan setiap hari pemberian ekstrak etanol daun parang romang secara oral selama 28 hari pada tikus putih jantan dan betina tidak memperlihatkan gejala toksik berupa perubahan pada kulit dan bulu, lethargi, tremor, kejang dan tidak adanya kematian pada tikus pada berbagai kelompok perlakuan dan kelompok kontrol

\section{KESIMPULAN}

Dari hasil penelitian dan pembahasan dapat ditarik kesimpulan yaitu Pemberian ekstrak etanol daun parang romang (B. virgata) dengan 3 variasi dosis selama 28 hari secara oral tidak menyebabkan perubahan profil hematologi tikus putih (Rattus novergicus)

\section{DAFTAR PUSTAKA}

1. Manggau, M., Hasan, H., Wahyudin, E., Haryono, K., Mufidah. And Lukman. Efek Farmakologi Tanaman Antikanker yang Digunakan oleh Masyarakat Sulawesi Selatan, Balitbangda Sulawesi Selatan. 2012 ; ISBN 9786028400558

2. Lukman, M., Rusdi, M., Hatta, M., Rahman, L., Subehan. and Manggau, M. Anti proliferation activity of Nanoencapsulated bioadhesive vaginal gel of isolated active Compound (BVI03) from Boehmeria virgata (Forst) guill leaves against human cancer cervix Hela cells. International Journal of Pharma Sciences and Research. 2014: Volume 6. 836-839.

3. Wardihan, Rusdi, M., Alam, G., Lukman. and Manggau, M. Selective Cytotoxicity Evaluation in Anticancer Drug Screening of Boehmeria virgata (Forst) Guill Leaves to Several Human Cell Lines: HeLa, WiDr, T47D and Vero. Dhaka Univ. J. Pharm. Sci. 2013 ; 12(2): 87-90.

4. BPOM. Pedoman Uji Toksisitas Nonklinik Secara In Vivo. Badan Pengawas Obat Dan Makanan Republik Indonesia ; 2014.

5. Ihedioha JI, Ugwuja JI, Noel-Uneke OA, Udeani IJ, Daniel-Igwe G. Reference Values for the Haematology Profile of Conventional Grade Outbred Albino Mice (Mus musculus) in Nsukka, Eastern Nigeria.ARI 2012 ; vol9(2):1601-1612

6. Hall Robert L. In: Andress, J.M., (Eds.). Animal Models in Toxicology. New York: Marcell Dekker Inc. page. $791 ; 1992$.

7. Harkness, J. E., Turner, P. V. and Vandewoude, S. Harkness and Wagner's Biology and Medicine of Rabbits and Rodents. $5^{\text {th }}$ ed. Ames : WilleyBlackwell; 2010

8. Qili, H., Guoming, S,.Keliang, L,. Fangcheng, Z.,Yong, J., Jun, G., Lida L.,Zhongren, J., Minwu, J.,Huiping, X. Sex-specific reference intervals of hematologic and biochemical analytes in Sprague-Dawley rats using the nonparametric rank percentile method. Journal Plos One. 2017; 1-18.

9. Douglass, JW.,Wardrop, KJ.Schalm's Veterinary Hematology. $6^{\text {th }}$ ed Wiley-Blackwell. p852-887; 2010

10. Bo Li B, Jin Y, Xu Y, Wu Y, Xu J, Tu Y. Safety evaluation of tea (Camellia sinensis (L.) O. Kuntze) flower extract: Assessment of mutagenicity, and acute and subchronic toxicity in rats. Journal of Ethnopharmacology. 2011;133:583-90

11. Smith CA, Andrews CM, Collard JK, Hall DE, Walker AK. Rats and Mouse. In: Color Atlas of Comparative Diagnostic \& Experimental Hematology. Barcelona: Wolfe Publishing/Mosby-Year Bok Europe Ltd.pp9-15; 1994

12. Sireeratawong $S$, Piyabhan $P$, Singhalak $T$, Wongkrajang $Y$, Temsiririrkkul $\mathrm{R}$, Punsrirat J, et al. Toxicity evaluation of sappan wood extract in rats. J Med Assoc Thail. 2010;93(7):S50-S57 